\title{
AZ IPAR 4.0 FOGALMA ÉS KRITIKUS KÉRDÉSEI - VÁLLALATI INTERJÚK ALAPJÁN
}

A tanulmány célja, hogy meghatározza az Ipar 4.0 fogalmát, rendszerezze technológiáit, és bemutasson néhány, a vállalatok számára kiemelten fontos felhasználási lehetőséget és problematikus kérdéskört. A szakirodalom maga is még ismerkedik a fogalommal, annak gazdasági hatásaival, ezért a cikk első lépésként összefoglalja, hogy a kutatók miként próbálták megfogalmazni az Ipar 4.0 jelenségét, majd egy egységes fogalmat alkot. Összegyűjti és feltárja azokat a technológiákat, amelyeket leggyakrabban alkalmaznak az Ipar 4.0-ban jártas vállalatok működésében, és felvázol egy folyamatot, amelynek során az Ipar 4.0 ki tud teljesedni egy vállalaton belül, majd pedig a digitális ökoszisztémában. A tanulmány összegyűjtött számos olyan problematikus kérdést is, amelyek az Ipar 4.0 megvalósításának gátat szabhatnak, így például a hiányzó digitális stratégia, az ismeretlen mértékű beruházástól való félelem, a munkaerő összetétele és felkészültsége és az adatbiztonság. A magyar nyelven megjelent, Ipar 4.0-val foglalkozó tanulmányok nagy része elméleti, aktuális vállalati gyakorlatot kevéssé tartalmaz. Jelen dolgozat erőssége, hogy empirikus része négy, vállalati szakemberekkel készült interjúra épül. A négy Magyarországon működő vállalat mind elindult az Ipar 4.0 megvalósításának útján, különböző lépcsőfokokat elérve. A vizsgált problémák közül az interjúk során legélesebben a munkaerővel kapcsolatos bizonytalanság és az adatbiztonság rajzolódott ki.

\section{Kulcsszavak: Ipar 4.0, digitalizáció, loT, big data, interjúk}

A történelem során az emberek mindig is törekedtek arra, hogy életszínvonalukat növeljék. Az ipar igyekezett lépést tartani a számban és változatosságban is növekvő vevői igényekkel, és maga is folyamatosan fejlödött. Ez vezetett el az első ipari forradalomhoz a XVIII. század végén - XIX. század elején, amikor is a textilipar drasztikus fejlödésen ment keresztül a korabeli Angliában, majd a gőzgépgyártás járult hozzá az életszínvonal emelkedéséhez (Mokyr, 1985).

A második ipari forradalom a XIX. század végén XX. század elején az elektromos áram és az általa üzemelő berendezések, a tömeggyártás és a belső égésű motorok széles körü elterjedése révén emelte új szintre az életszínvonalat széles társadalmi rétegekben (Mokyr, 1998).

A harmadik ipari forradalom kezdete a XX. század közepén a számítógépek megjelenésével hozható összefüggésbe (Greenwood - Jovanovic, 1999).

Több tanulmány (Monostori, 2014; Heynitz et al., 2016; Geissbauer et al., 2016) és az elkészített interjúk is azt mondják, hogy a negyedik ipari forradalom már elkezdődött. A korábbi termelési rendszerek már nem tarthatók fenn soká, hiszen tartós környezeti károkhoz (klímaváltozás) vezettek, túl sok nem-megújuló energiaforrást emésztenek fel, továbbá az öregedő társadalmak miatt fel kell készülni a munkaerő létszámának csökkenésére (Wang et al., 2016a). A negyedik ipari forradalom tehát nemcsak a termelési rendszerekre, hanem a társadalomra is hatást gyakorló jelenség. Az emberi munkaerő kiváltására a robotok és az automatizáció régóta létezik. Az internet viszont ezek hálózatba kötésével forradalmasítja a folyamatszervezést. Kritikusok megemlítik, hogy mivel a digitalizáció fellendülése a számítógépes technológia fejlődésére vezethető vissza, tulajdonképpen nem negyedik ipari forradalomról, hanem a harmadik kiteljesedéséröl beszélhetünk (Holodny, 2017; Jensen, 1993). A dolgozat ugyanakkor nem erre a megközelítésre épül. A negyedik ipari forradalom alapja a digitalizáció és az adat, a számítógép csupán eszköz. Az internet és a technológia fejlődése megteremti az emberek, gépek és vállalatok folyamatos összeköttetésben lévő hálózatát, és az értékteremtő folyamatok adatainak folyamatos megosztásával elérhetővé válik a versenyképes, a vevő számára teljesen testreszabott termék előállítása. A versenyelőny forrása tehát nem csupán az összehangolt, vagy éppen teljesen új alapokra helyezett termelés ( $\mathrm{pl}$. additív termelés) lesz, hanem a termékek digitális szolgáltatásokkal való körbeágyazása, valamint, hogy melyik vállalat hogyan válogatja ki a keletkező adatokból a releváns információt a döntéshozatal támogatásához (V1, V2, V3, 2017; Heynitz et al., 2016; Deloitte, 2015; Geissbauer et al., 2016).

Jelen tanulmány három kutatási kérdésre keresi a választ. Elsöként, hogyan értelmezik a magyar vállalatok az Ipar 4.0-t, milyen megközelítést alkalmaznak? Másodsorban, habár a vizsgálat nem lesz reprezentatív, a tanulmány rá kíván mutatni, milyen utat járnak be a vállalatok a fejlesztések során, milyen lépések sorozatán keresztül realizálódik az Ipar 4.0? Harmadik kutatási kérdés, hogy az azonosított, Ipar 4.0 megvalósítását akadályozó tényezőket a vállalatok miként kezelik? A kutatási kérdések megválaszolásához négy különböző termelővállalatnál készített interjú tapasztalatait használtam fel.

A tanulmány felépítése a következő: elsőként az Ipar 4.0 szerteágazó fogalmát mutatom be, majd azokat a technológiákat írom le, amelyek révén kialakul és kiteljesedik egy vállalatban, illetve a szervezetközi kapcsolatokban. Ezt követően a tanulmány egy fejezete foglalkozik azokkal a problémákkal, amelyek megnehezítik, gátolják az Ipar 4.0 elterjedését a vállalatokban. A kutatási kérdések megfogalmazása után a kutatásmódszertant ismertetem, majd az eredményeket részletesen bemutatom. A disz- 
kusszió során az eredmények értékelésére kerül sor. Az összefoglalás a föbb eredményekre és a jövőbeli kutatási kérdésekre tér ki.

\section{Az Ipar 4.0 fogalmának és vállalati alkalmazásának kérdései}

A fejezet során az Ipar 4.0 fogalmának körüljárására és azoknak az alapvető technológiáknak az áttekintésére kerül sor, amelyeket az empirikus vizsgálatok szerint a vállalatok az Ipar 4.0 megvalósítása szempontjából szükségesnek tartanak. A fejezet foglalkozik a megvalósítást akadályozó tényezőkkel is.

\section{Az Ipar 4.0 fogalma}

A fejezet célja az Ipar 4.0 fogalmának meghatározása, elhatárolása a negyedik ipari forradalomtól és az ipari digitalizációtól. A korábbi fejezetben szó esett az ipari forradalmakról, mint a gazdaságra és társadalomra széles körü hatást kifejtő fejlődésről, melyeknek motorja jellemzően a termelési rendszerek megváltozása. A negyedik ipari forradalom egy tág, míg az Ipar 4.0 egy szükebb, a vállalati szférát középpontba helyező jelenség. A következő bekezdésekben ez utóbbi fogalom tisztázására kerül sor.

Az Ipar 4.0 megnevezést 2011-ben használta először a német kormányzat, amikor meghirdette 2020-ig tervezett iparfejlesztési programját (Zhou et al., 2015). Hofmann és Rüsch (2017) szüken értelmezik az Ipar 4.0 fogalmát, a termelésre koncentrálva. Megközelítésük szerint akkor beszélhetünk Ipar 4.0-ról, ha a termékek, eszközök és akár a szolgáltatások is hálózatba vannak kapcsolva. Az újabb ipari forradalmat az internet hajtja, amelyen keresztül nemcsak az emberek, hanem a gépek is kommunikálnak egymással a kiber-fizikai rendszerben (cyber-physical system, CPS). Az Ipar 4.0 létrehozza az intelligens terméket és termelési folyamatot (Brettel et al., 2014). Ez a szűkebb értelmezés az ipari digitalizáció, hiszen e megközelítések leegyszerüsítik az Ipar 4.0-t a termelési folyamatra és a technológiai eszközök alkalmazására, pedig az bőven teremt lehetőséget a vállalat más szervezeti egységeinek is az adatok elemzésére, felhasználására, valamint okoz szervezeti változásokat is.

Heynitz és szerzőtársai szerint (2016, p. 2.) az Ipar 4.0 úgy ragadható meg, mint valami, ami integrálja a vállalat értékteremtő tevékenységeit és az egész értékteremtési láncot a digitalizáció segítségével. Majdnem szó szerint így fogalmaznak Geissbauer és szerzőtársai is (2016), akik az Ipar 4.0 célját úgy látják, az valamennyi fizikai eszköz digitalizációjára törekszik, hogy egy digitális ökoszisztémában egyesítse azokat az értékteremtési láncban együttműködő partnerekkel együtt. Müller és társai (2017) szerint az Ipar 4.0 középpontjában a valós idejü, intelligens, horizontális és vertikális hálózatépítés áll, amelyben emberek, gépek, tárgyak kapcsolódnak öszsze, információs és kommunikációs technológiák járul- nak hozzá a komplex rendszerek dinamikus kezeléséhez. Hermann és szerzőtársai (2016) szerint az Ipar 4.0 tág fogalom, és az értéklánc megszervezésének újfajta technológiáit és koncepcióit foglalja magába. Habár Hermann értelmezésében már található utalás a szervezeti változásokra (értéklánc), még ez a megközelítés sem közvetíti azt, ami a legfontosabb, hogy teljesen újra kell tervezni a vállalati stratégiát és üzletmenetet. Kovács (2017) szerint az Ipar 4.0 tulajdonképpen az információs és kommunikációs technológiának a korábbiaknál szélesebb felhasználása, mert nemcsak az üzleti, hanem a kormányzati és civil szférában egyaránt alkalmazható. A szerzők már előre vetítik azt is, hogy a digitális technológia révén összeköttetésbe kerülő szervezetek nemcsak üzleti partnerek lehetnek. Ez a fokú integráció azonban igényli a rendszerek standardizálását (szabványosítását), hatalmas tőkeberuházást és olyan fokú bizalmat a digitális ökoszisztéma tagjai között, amely nem magától értetődő minden ország vállalati kultúrájában.

Horváth és Szabó (2017) felhívják a figyelmet arra, hogy a megváltozott üzleti környezetben, ahol a vállalatoknak erősödő versennyel kell szembenézniük, elengedhetetlen, hogy növeljék innovációs kapacitásukat, képesek legyenek reagálni a folyamatosan változó vevői igényekre, a rövidülő termékéletciklusra, és termelési rendszereiket e tényezőkhöz igazítsák. Az Ipar 4.0 a vállalatok jövőbeli versenyképességének alappillére lesz, és számos mikro- és makroszintű változásra kell felkészülni. Hasonlóan vélekedik Schwab (2016) is, aki szerint az Ipar 4.0 technológiák fúziója, amely elmossa a határvonalakat a fizikai, a digitális és a biológiai szférák között. Rákényszeríti a vállalatokat, hogy a folyamatos innováció érdekében kombinálják a technológiai megoldásokat, amely pedig szükségessé teszi azt, hogy a felső vezetés újragondolja az üzletvezetés menetét. Prause (2015) szerint az Ipar 4.0 új üzleti modelleket és struktúrákat kíván, amely átalakítási folyamat maga a digitális transzformáció.

A bemutatott meghatározások egyetértenek abban, hogy az Ipar 4.0 áthatja az egész vállalati értékláncot igaz legtöbben az értékláncot a termelésre, esetleg logisztikával kiegészítve az értékteremtő folyamatokra értelmezik (1. táblázat). Kiterjedése túlnőhet a vállalat határain, átfogva az ellátási láncot, vagy még tágabb értelemben az ellátási hálózatot. Újfajta, hálózatba kötött technológiai eszközökre épít, és új eljárásokat tesz szükségessé, amely újfajta képességeket igényel a vállalatoktól, és ez akár új üzleti modellek kialakítását is szükségessé teheti. Az Ipar 4.0 tehát egy olyan jelenség, amely technológiai eszközökre épitve, tevékenységek összessége révén, a digitalizáció adta lehetőségek kiaknázásával magas szintre emeli a folyamatok átláthatóságát, integrálja a vállalati értékláncot és az ellátási hálózatot, új szintre emelve a vevői értékteremtést a testreszabott és okostermékek elérhetövé tétele révén. 


\begin{tabular}{|c|c|c|}
\hline Forrás & Az Ipar 4.0 fókuszpontjai & Az Ipar 4.0 megközelitése \\
\hline Hofmann - Rüsch (2017) & termelés & termelés \\
\hline Brettel et al. (2014) & termelés, a termelési folyamat integrációja & termelés \\
\hline Heynitz et al. (2016) & értékteremtő folyamatok horizontális integráció & értékteremtő folyamatok \\
\hline Geissbauer et al. (2016) & horizontális és ertikális integráció & értékteremtő folyamatok és vállalatközi folyamatok \\
\hline Müller et al. (2017) & horizontális és vertikális integráció & értékteremtő folyamatok és vállalatközi folyamatok \\
\hline Hermann et al. (2016) & $\begin{array}{l}\text { értékteremtő folyamatok } \\
\text { vállalat belső struktúrájának átalakítása }\end{array}$ & értékteremtő folyamatok \\
\hline Kovács (2017) & $\begin{array}{l}\text { horizontális és vertikális } \\
\text { integráció kiegészítve az állami és civil } \\
\text { szférával }\end{array}$ & $\begin{array}{l}\text { értékteremtő folyamatok és } \\
\text { szervezetközi folyamatok }\end{array}$ \\
\hline Horváth - Szabó (2017) & $\begin{array}{l}\text { üzletimodell-váltás } \\
\text { integráció } \\
\text { szervezeti változások }\end{array}$ & szervezeti \\
\hline Schwab (2016) & $\begin{array}{l}\text { integráció } \\
\text { üzletimodell-váltás }\end{array}$ & szervezeti \\
\hline Prause (2015) & $\begin{array}{l}\text { üzletimodell-váltás } \\
\text { vállalat belső struktúrájának átalakítása }\end{array}$ & szervezeti \\
\hline Saját meghatározás & horizontális és vertikális integráció & értékteremtő folyamatok és vállalatközi folyamatok \\
\hline
\end{tabular}

\section{1. táblázat Az Ipar 4.0 meghatározások sajátosságai (saját szerkesztés)}

Habár az Ipar 4.0 elsődleges megjelenési helye a termelés, a cikk rá kíván mutatni arra, hogy a vállalat más müködési területeinek is nyújt kiaknázható lehetöségeket. Nemcsak a termelésből származó adatok elemzése válik lehetővé, hanem a termékek és a partnerektől származó információk sokasága is. Ebben a fejezetben ezeket a technológiákat mutatom be.

\section{Az Ipar 4.0 alapvető technológiái}

A fejezet áttekinti, hogy az egyes kutatóintézetek, kutatók mit tekintenek az Ipar 4.0 megvalósítás alapköveinek. Ezek egyrészt eszközök, másrészt módszerek, folyamatok, rendszerek, amelyek egy, az Ipar 4.0 lehetőségeit kihasználó, élenjáró vállalat gyakorlatát képezik.

A Geissbauer és szerzőtársai (2016) közölnek egy listát azokról az elemekről, amelyek szerintük az Ipar 4.0 megvalósítását szolgálják. Három szintjét értelmezik az eszközök alkalmazásának. Az első szinten a termelési folyamat digitalizációja zajlik, a másodikon mindezek kiterjesztése a partnerkapcsolatokra is, majd pedig új termék-szolgáltatás portfóliók kidolgozása:

1. a belső és külső értéklánc digitalizációja és integrációja: IoT (Internet of Things - dolgok internete) platformok, mobileszközök, felhőalapú szolgáltatások,

2. az üzleti modell és a vevőelérés digitalizációja: additív termelés, azonosítás és visszaélések feltárása, magas szintü ember-gép interfészek, helymeghatározó technológia,

3. a termék- és szolgáltatásportfólió digitalizálása: big data elemzések és fejlett algoritmusok, kiterjesztett valóság, többszintű vevői interakciók és vevőprofil-alkotás, szenzorok.

Mivel a felsorolt technológiák tartalma nem mind közismert, szükséges azok rövid magyarázata. Hermann és szerzőtársai (2016) szerint az IoT esetében a „dolgok” chip-pel, RFID-val (Radio-frequency Identification, rádiófrekvenciás azonosítás), szenzorral, vagy bármilyen más, hálózati csatlakozásra képes eszközzel vannak felszerelve, képesek kommunikálni és adatot megosztani. Az általuk folyamatosan termelt és a hagyományos adatelemzési rendszerek számára kezelhetetlenül nagy mennyiségben keletkező adatokat nevezzük big data-nak (Laney, 2001; Wang et al., 2016b). Ezeknek az összegyüjtése és a jogosultakkal való megosztása vállalati adattárházak, vagy felhö, esetleg felhőszolgáltató által (pl. Amazon, Microsoft) lehetséges (Rüssmann et al., 2015). A sok adat akkor igazán értékes, ha van eszköz, ami képes feldolgozni, elemezni, és utána az eredményeket felhasználóbarát formában a jogosultak számára rendelkezésre bocsájtani. Ez a big data analytics, amely akár versenyelőny forrása is lehet. A kiterjesztett valóság valóságos környezetbe (pl. egy termelési vagy karbantartási folyamatba) helyez bele valós és virtuális tárgyakat vagy a dolgozót, interaktív, három dimenziós és valós idejü (Krevelen - Poelman, 2010). Felhasználásának módja lehet, ha 3D szemüvegen keresztül mutatnak be egy gyártósor-karbantartást, hogy amikor arra ténylegesen sor kerül, a dolgozó el tudja azt végezni (Rüssman et al., 2015). Az additív termelés lényege, hogy rétegről rétegre adja hozzá a szükséges alapanyagot a termékhez a termelési folyamat során, nem pedig kimetszi, kivágja, elveszi azt egy nagyobb alapanyag-mennyiségböl (Heynitz et al., 2016; Rüssmann et al., 2016). Az embergép interfészek olyan - ideális esetben ergonomikus és felhasználóbarát - kezelőfelületek (hardver és/vagy szoftver), ahol a gép és az azt felügyelő ember kommunikálni tud egymással.

Hermann és szerzőtársai (2016) ötven tanulmányra kiterjedő irodalomelemzésük révén négy alapvető eszközt azonosítottak, amelyek szükségesek az Ipar 4.0 vállalaton belüli megvalósításához. Ezek a CPS, az Internet of Things, az Internet of Services (IoS) és a Smart Factory. Ezek is önmagukban átfogó kategóriák és nem nevesítik 
azokat a konkrét technikai eszközöket (pl. szenzor), ami által pl. a CPS müködhet. A CPS a fizikailag megjelenő eszközöket köti össze a kibertérrel. Szenzorokat, 3D szkennereket, kamerákat vagy RFID-t használ, és adatot termel az adott folyamatról. Ez tulajdonképpen az IoT megvalósulása (Hermann et al., 2016). A kimondottan termelésben használt CPS-megoldás, a CPPS (cyber-physical production system) a termelőeszközök, dolgozók, akár készülőfélben lévő termékek hálózatba kapcsolt rendszere (Lee et al., 2014). Lehetővé teszi a termelési folyamat rugalmassá tételét és hatékonyságának javítását, testreszabott termékek készítését tömegtermelési módszerekkel (Weyer et al., 2015). Az $I o S$ lehetővé teszi a szolgáltatóknak, hogy szolgáltatásaikat az internet segítségével értékesítsék (Hermann et al., 2016). Az okosgyár (smart factory) tulajdonképpen az előbbiek sikeres alkalmazása esetén, a digitalizáció segítségével vertikálisan és horizontálisan integrált gyárat jelenti, amely így még nagyobb vevői érték létrehozására képes.

Rüssman és szerzőtársai (2015) kilenc olyan technológiát gyüjtöttek össze, amelyek a negyedik ipari forradalom élenjáró vállalatait jellemzik. Ezek között találhatók technikai eszközök és szervezési módszerek is:

- autonóm robotok,

- szimuláció,

- horizontális és vertikális rendszerintegráció,

- Ipari IoT (IIoT), (ami gyakorlatilag a CPPS),

- kiberbiztonság,

- felhőalapú szolgáltatások,

- additív termelés (3D nyomtatás),

- kiterjesztett valóság,

- big data elemzés.

E felsorolásban az újonnan megjelenő technológiák az autonóm robotok, amelyek nemcsak elvégeznek egy számukra kijelölt feladatot repetitíven, hanem összekapcsolódnak akár egymással, akár az emberi munkaerővel, felismerik a feladatot, képesek tanulni és reagálnak a környezetükben bekövetkező változásokra (Szalavetz, 2016).

Zhou és szerzőtársai (2015) négy kritikus technológiát azonosítanak az Ipar 4.0 megvalósítása kapcsán. Egyrészt a már korábban is említett kiber-fizikai rendszereket (CPS) és a kiber-fizikai termelési rendszereket (CPPS), másrészt a mobilinternet és más IoT-technológiákat, harmadrészt a felhőalapú adattárolási rendszereket és végül a big data elemzési rendszereket.

Látható, hogy míg Geissbauer és szerzőtársai munkájában csoportosítva, Hermann és társai, Rüssman és társai, valamint Zhou és társai esetében a technológiai eszközök és szervezési kérdések vegyesen jelennek meg. A továbbiakban a tanulmányban az összetartozó eszközöket és szervezési módszereket csoportosítva ábrázolom, és részletesen bemutatom őket.

Wang és szerzőtársai szerint (2016a) az Ipar 4.0 megvalósításához szükség van (1) az értéklánc horizontális integrációjára, (2) a hálózatba kapcsolt gyártási rendszerre és vertikális integrációra, továbbá (3) a műszaki tervezés end2end digitalizációjára az egész értéklánc mentén.
Olyan feltörekvő technológiákról is írnak, amelyek ezek megvalósítását támogatják, így az IoT, a vezeték nélküli szenzor hálózatok, a big data, a felhőalapú szolgáltatások, a beágyazott rendszerek és a mobilinternet.

Wang és társai (2016a) cikkének esetében már megjelenik az a megközelítés, amelyet a tanulmány is követni fog, miszerint szétválasztja azokat a technológiai eszközöket, amelyek lehetővé teszik a digitalizációt és az integrációt, és azokat az újfajta szervezési módszereket, eljárásokat és folyamatokat, amelyek megvalósítása révén egy vállalat ki tudja használni az Ipar 4.0 lehetőségeit.

Az Ipar 4.0 megvalósításának egy vállalatban, illetve vállalati határokon átívelően vannak alapkövei, amelyekben még a szakirodalom nem egységes, és amelyek részben egymásra is épülnek. A korábban említett szerzők felsorolásában is vegyesen vannak jelen ezek a technológiai eszközök és vezetési módszerek, amelyek mindenképpen újfajta gondolkodásra és lépésröl lépésre történő fejlesztésre késztetik a vezetőket. Összefoglalva, a következő lépéseket azonosítottam, mint a technológiák és szervezési megoldások adaptálásának lépcsőfokait:

1. Eszközök, technológiák alkalmazása, hálózatba kötése, a teljes vállalati üzleti folyamat átláthatóságának biztosítása érdekében, például szenzorok, RFID, IoT, IIoT, CPS, CPPS, autonóm robotok, automatizáció, additív termelés, felhőalapú adattárolás és big data révén.

2. Horizontális integráció, amely a vállalaton belüli tevékenységi területek szoros, valós idejü összeköttetését, adatmegosztását és együttmüködését jelenti. Eszközei lehetnek a felhő, a big data, a big data elemzés, a szimuláció, a kiterjesztett valóság. Mindez nem kis részben már szervezési kérdés is.

3. Vertikális integráció, amely elsődlegesen az ellátási láncban együttmüködő partnerekkel való együttmüködést, digitális összeköttetést foglalja magába. Ez a fázis is jelentős fejlődést igényel vezetési és szervezési szempontból a vállalatok részéről és technológiai háttere azonos az előző pontban olvashatókkal.

4. Az üzleti modell újragondolása a vevőközpontúság jegyében, akár a szervezeti struktúra átalakításával.

Az Ipar 4.0 adaptálásának folyamata tehát nem egyik napról a másikra következi be, különösen a harmadik és negyedik fázis kialakítása vesz igénybe hosszú időt és igényel a felektől magas szintü elköteleződést. A technológiai eszközök kiválasztásánál és bevezetésénél is fontos szempont, mi hogyan fog egymásra épülni a rendszerben, és hogyan fog hozzájárulni a teljes folyamat hatékonyságának növeléséhez.

\section{Az Ipar 4.0 eszközei és a digitális ökoszisztéma felépítése}

A fejezet célja, hogy bemutassa, a szakirodalom szerint a korábban felvázolt technológiák, vezetési és szervezési módszerek, eljárások miként alkotnak egységes rend- 
szert és hatják át a vállalaton belüli és a vállalatok közötti együttmüködést.

Amint arról már volt szó, az Ipar 4.0 megvalósításához nélkülözhetetlenek olyan eszközök, amelyek az adatokat generálják, létrehozva a big data-t. A gépekből származó adat middleware segítségével alakul át információvá, amely egy közbülső szoftver a technológiai eszköz és az applikáció között (Atzori et al., 2010), ahol a keletkezett adatot az ember felhasználóbarát módon használni tudja, leggyakrabban valós időben. További eszközök gyüjtik és tárolják az adatokat, mint például a felhő vagy a helyi adattárházak, és interfészek segítségével juttatják el más rendszerekbe, pl. az ERP-be. Kellenek olyan platformok, amelyek közös alapot adnak mindezen gépeknek és eszközöknek, illetve olyan standard, vagy mindezidáig leggyakrabban házon belül fejlesztett szoftverek, amelyek a keletkező adatokból leszürik a releváns információt ( $\mathrm{pl}$. adatbányászat és adatelemzés, szimulációk, algoritmusok) és azokat a felhasználók számára kényelmes módon és eszközön, azaz platformon (tablet, mobiltelefon) jelenítik meg egy applikáció segítségével.

Az integrációt a fenti ,dolgok” (things) valamennyi darabjának internet/hálózati csatlakozása és egymással való valós idejü összekapcsolódása hozza létre.

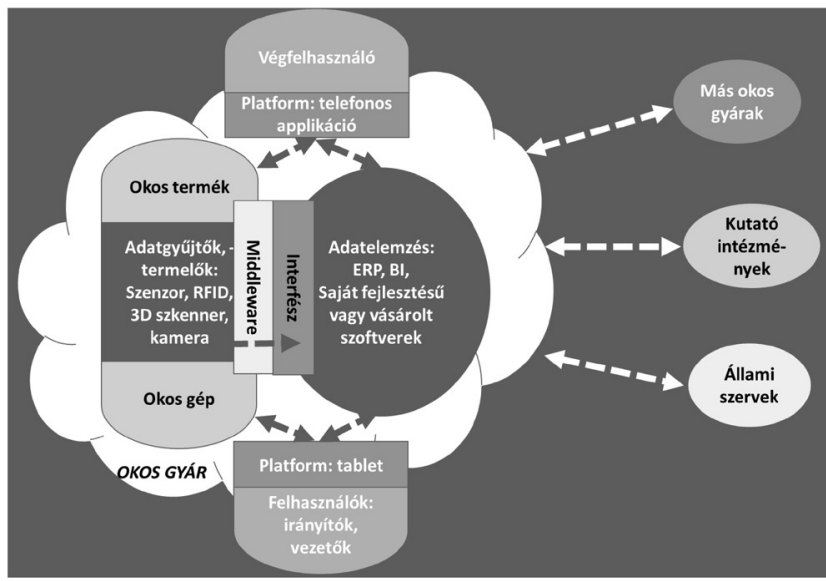

1. ábra A digitális ökoszisztéma (saját szerkesztés)

Az 1. ábra összefoglalja azokat a technológiákat és folyamatokat, amik a digitális ökoszisztémában, a vállalatok hálózat által összekapcsolt, valós idejü közösségében zajlanak. Az információk elérhetővé válnak a különböző szintü vállalati döntéshozók számára, összetettség és hozzáférési jogosultság alapján, vagy éppen a terméket használó fogyasztóknak. Az információ továbbítása révén pedig valamilyen döntés, jóváhagyás vagy beavatkozás történik - akár automatizáltan is. Ha a digitalizáció révén ilyen összetett integráció jön létre, azt nevezzük a ,jövő gyárának” vagy „okosgyárnak”, amely képes a termelési és müködési folyamatok folyamatos optimalizálására, pontos adatokra alapozott döntésekkel. Ha ezek a vállalati határokon átívelnek és az adatok okosgyárak között is megosztásra kerülnek, az a digitális ökoszisztéma. További lehetőség, ha az adatmegosztás a folyamatok fejlesztésében részt vevő kutató intézetekkel, egyetemekkel is megvalósul, vagy akár a kormányzattal pl. a pénzügyi bevallások automatikus elkészítése és benyújtása kapcsán.

\section{Az Ipar 4.0 megvalósítását akadályozó tényezők}

A vállalatok negyedik ipari forradalomba való bekapcsolódása egy ideig még döntés kérdése. Sok tanulmány olvasható arról, hogy az új ismeretlen technológiák alkalmazása, kifejlesztése kockázatos és drága, de számottevő megtakarítás és bevételnövekedés érhető el a korán ébredők számára (Geissbauer et al., 2016; Deloitte, 2015; Heynitz et al., 2016). Vannak olyan iparágak, ahol nem lehet elkerülni a haladást és a fejlesztések, alkalmazások tempójának felvételét a versenyben maradás érdekében (autóipar, elektronika), de vannak olyan iparágak is, akik majd csak akkor lépnek az ilyen jellegű fejlesztések útjára, ha az ösvényt már kitaposták, és a technológia a kisebb profitrátával müködő ágazatok számára is megfizethető lesz.

Geissbauer és szerzőtársai a PwC 2016-ban készített Globális Ipar 4.0 Felmérésének (GIF) eredményeit foglalják össze, amelynek keretében 26 ország 2000 szakemberét kérdezték meg arról, hogyan fogja kiaknázni vállalatuk a digitalizáció nyújtotta lehetőségeket. A felmérésben megkérdezett vállalatok döntö többsége (52\%) szerint az Ipar 4.0 megvalósításának legnagyobb gátja a tiszta és világos digitális stratégia az értékteremtő (termelési és logisztikai) folyamatokban, valamint a vezetőség támogatásának hiánya (Geissbauer et al., 2016). Porter és Heppelmann (2014) az öt erő alapos vizsgálatát javasolják, amelyek mentén áttekinthető, hogy azokat a digitalizáció miképpen befolyásolja, és az adott vállalat stratégiáját hogyan érinti. A tanulmány a digitális érettséget Geissbauer és szerzőtársai (2016, p. 28.) alapján értékeli, akik a digitális stratégia megvalósításának szintjei szerint megkülönböztetik a digitális újonc, a horizontális integrátor, a vertikális integrátor és a digitális bajnok kategóriákat.

A GIF felmérés szerint sok cég fél a digitális beruházások jelenleg még ismeretlen mértékü gazdasági hasznától (38\%), és a magas beruházási költségektől (36\%). Geissbauer és társai (2016) kutatásában az egyes iparágak Ipar 4.0 beruházásait is vizsgálták, és azt találták, hogy a legnagyobb beruházások az elektronikai iparban vannak és várhatók is a jövőben, 2020-ig mintegy 243 milliárd dollár értékben évente. A legtöbb cég úgy látja, a befektetett pénz két éven belül megtérülhet, de a válaszadók kevésbé optimista egyharmada is 3-5 éves megtérülési idővel számol.

A GIF válaszadóinak negyede jelölte meg kockázatos tényezőként az adatbiztonságot, különösen, mikor külső adatszolgáltatásról vagy adatforrásokról van szó. A keletkező hatalmas mennyiségü adat biztonságos tárolása és kezelése komoly kihívás elé állítja a vállalatokat, hiszen a dolgozókról, folyamatokról, terméktervezésröl, prototípusokról szóló adatok és információk védelme újfajta gondolkodást igényel. Geissbauer és társai felmérése szerint (2016) a vállalatok leginkább a kiberbiztonsági rendszerek sérülése miatt bekövetkező működési zavaroktól és az adatvesztéstől, valamint az ebből fakadó felelősségi kockázatoktól tartanak. 
A GIF-felmérés szerint ugyanennyien tekintik akadályozó tényezőnek a nem megfelelö képzettségü munkaeröt. Nagyon sok helyen olvashatunk arról, hogy az Ipar 4.0 az alacsony vagy középszintü, könnyen automatizálható munkakörök tömegét fogja megszüntetni, átalakítani (Frey - Osborne, 2017; Szalavetz, 2016). Szalavetz 2016-os írásában a World Economic Forum elemzését idézve azt mondja, az amerikai állások 9 százaléka teljes mértékben kiváltható automatizálással, de az ipari robotok és a gépi tanulás az állások 47 százalékát veszélyeztetik. Sok alacsony hozzáadott értékü munkát kiváltanak majd gépek, de valójában több munkaeröre lesz szükség, csak másmilyen képességekkel, mint most (Csurgó, 2017). Kritikus kérdés például, hogy a digitalizáció vívmányainak kihasználásához, a versenyelőny eléréséhez nemcsak jó minőségü és jól kiválasztott adatokra, hanem kiváló elemzésekre is szükség van, nagy jelentősége lesz tehát a big data elemzésre képes, és az elemzést elvégző szoftvereket, szimulációkat programozni tudó dolgozóknak. Helyes döntéseket ugyanis csak erre lehet alapozni (Hazen et al., 2014).

Fontos hátráltató tényezője az Ipar 4.0 vívmányai elterjedésének, hogy még nem állnak rendelkezésre szabványok, normák és tanúsitványok, amelyek biztosítanák a különböző rendszerek összekapcsolhatóságát. A GIF válaszadói szerint egyelöre még lassan terjednek a digitális infrastruktúra alapvető technológiai eszközei, nem feltétlenül állnak rendelkezésre minden beszállító vagy vevő szervezetében, így az együttműködés is korlátozott lehet. Az MTA SZTAKI Ipar 4.0 felmérés eredményei szerint, a magyarországi vállalatok 25 százaléka még az adatok gyüjtését sem kezdte el, tíz százalék, habár gyűjti, de nem elemzi azokat, 32 százalék nem tudta, hogy cége végez-e adatgyüjtést, és mindössze 36 százalékuk elemzi, hasznosítja őket (Nick, 2017).

A GIF eredményei szerint a cégek 14 százaléka attól is tart, hogy elveszti a kontrollt a vállalat intellektuális vagyona felett. A vállalat vagyonát tekintve az immateriális javak (tudás, szellemi tulajdon, szabadalmi jogok) felértékelődésére lehet számítani, mindamellett, hogy a beruházási érték és a befektetett tárgyi eszközök volumene is folyamatosan nőni fog (Kovács, 2017; Heynitz et al., 2016). A vállalati tudásmenedzsmentnek nagyon fontos szerep jut majd, hiszen a szervezetben megtalálható tudás, képességek nyilvántartása, azok folyamatos aktualizálása versenyelőny forrása lehet (Horváth - Szabó, 2017).

Összefoglalva az Ipar 4.0 megvalósítását gátló legfontosabb tényezők a következők lehetnek:

- a világos digitális stratégia hiánya,

- az ismeretlen mértékü beruházástól és megtérüléstől való félelem,

- az adatbiztonság,

- a munkaerővel kapcsolatos tényezők,

- a szabványok hiánya,

- az attól való félelem, hogy a vállalat elveszti a kontrollt intellektuális vagyona felett.

A következő fejezetekben a kutatási kérdéseket és a módszertant röviden bemutatom, majd a kutatási kérdéseket válaszolom meg.

\section{Kutatási kérdések és kutatásmódszertan}

A fejezet célja, hogy bemutassa azokat a kutatási kérdéseket, amelyekre a tanulmány választ keres, valamint a módszert, amellyel e kérdések vizsgálatára sor kerül.

Jelen tanulmány három kutatási kérdésre keresi a választ. Elsőként, hogyan értelmezik a magyar vállalatok az Ipar 4.0-t, milyen megközelítést alkalmaznak? Másodsorban, habár a vizsgálat nem lesz reprezentatív, a dolgozat rá kíván mutatni, milyen utat járnak be a vállalatok a fejlesztések során, milyen lépések sorozatán keresztül realizálódik az Ipar 4.0? Harmadik kutatási kérdésként arra keresi a szerző a választ, hogy az összegyüjtött kritikus kérdéseket miként látják a vállalatok az Ipar 4.0 megvalósítása során?

A téma újdonságtartalmánál és a vizsgált technológiák alacsony elterjedtségénél fogva nagy tömegü, reprezentatív mintavételre nem volt lehetőség. A vállalati interjúk jól megválasztott vállalatoknál zajlottak, akik már elmélyedtek az Ipar 4.0 témában, ami lehetőséget nyújtott annak megvizsgálására, hogy a kutatási kérdésekben megfogalmazott problémák miként jelennek meg a valóságban, és orientálják a jövőbeni kutatásokat (Horváth - Mitev, 2015).

A tanulmány empirikus része négy vállalati interjún alapszik. A vállalatok kiválasztása részben a Nemzeti Technológiai Platform (NTP) tagjainak listájából történt, részben hólabdamódszerrel. A vállalaton belül a megkérdezett szakemberek kiválasztása ugyancsak hólabdamódszerrel zajlott, azaz az egyes interjúk végén az interjú alanyok iparági tapasztalataik alapján javaslatot tettek vállalatok és személyek megkeresésére, akik konferencia vagy egyéb ágazati szereplések révén kompetensek a témában. Az első interjút követően e módszer alapján történő megkeresések mindhárom esetben sikeres interjút eredményeztek.

A megkérdezett Magyarországon müködő vállalatok az Ipar 4.0 fogalmát már magukévá tették, és az vállalatuk müködését napi szinten befolyásolja, fejlődésük meghatározója. Az interjúk tapasztalatai a termelés mellett több más vállalati területet érintve csatolnak vissza az elméleti megközelítéshez, és ezeken keresztül bepillantást nyerhetünk, hogy egyes magyarországi termelővállalatok (egyes esetben anyavállalatuk) milyen lépéseket tettek a digitális fejlődés érdekében, milyen kihívásokkal szembesülnek, és tapasztalataik benchmarkként használhatók más, a fejlesztéseket fontolgató vállalat számára.

A vállalatok többségében külföldi tulajdonban álló nagyvállalatok, de egy magyar KKV is szerepel a mintában (ez a vállalat árbevétele szerint nagyvállalat, dolgozói létszáma szerint középvállalat, a többi vizsgált vállalattal való összehasonlításban maradt a KKV-kategóriában). A nagy cégek mind 1000 fő körüli vagy még nagyobb számú dolgozóval müködnek, árbevételük euróban is százmilliós, egy esetben milliárdos nagyságrendü.

A négy darab, egyenként 60-90 perces, félig strukturált interjú során a kérdések érintették, hogy a vizsgált vállalatban miként értlemezik az Ipar 4.0-t, milyen technológiai eszközöket, szervezési módszereket kezdtek el használni, van-e ezek között egymásra épülés, van-e digitális stratégia, és milyen tapasztalataik vannak mindezek- 
kel. Külön kitértünk a nagy mennyiségü adat tárolásának, felhasználásának problematikájára és az adatbiztonsági kérdésekre. A munkaerővel kapcsolatos kérdéseknek is külön blokkot szenteltünk az interjúban. Részletesen foglalkoztunk azokkal a kérdésekkel, amelyek akadályozhatják a digitális technológiák terjedését (2. táblázat). során e vállalattal interjút készíteni, de méretéből adódóan nehéz volt konkrét felelőst elérni. A V3 vállalatot a gyárigazgató-helyettesének útmutatása alapján választottuk ki az Ipar 4.0 kapcsán leginkább agilis gyáregyeség, és azon belül egy fejlesztési csoportvezető. A magyar telephely sok területre kiterjedően, számos Ipar 4.0 projektet futtat. A

\begin{tabular}{|c|c|c|c|c|c|}
\hline Megnevezés & $\begin{array}{l}\text { Cég tulajdonosi hát- } \\
\text { tere }\end{array}$ & Iparág & Az interjúalany beosztása & Régió & $\begin{array}{l}\text { Arbevétel/ } \\
\text { Létszám (2016) }\end{array}$ \\
\hline V1 & magyar & elektronika & ügyvezető & Közép-Dunántúl & $\begin{array}{l}4 \mathrm{M} € \\
75 \text { fó }\end{array}$ \\
\hline V2 & amerikai & autóipar & lean \& six-sigma manager & Közép-Dunántúl & $\begin{array}{l}176,5 \mathrm{M} € \\
1500 \text { fó }\end{array}$ \\
\hline V3 & belga & autóipar & $\begin{array}{l}\text { operations } \\
\text { manager }\end{array}$ & Dél-Alföld & $\begin{array}{l}113 \mathrm{M} € \\
900 \text { fö }\end{array}$ \\
\hline V4 & német & autóipar & csoportvezető & Észak-Magyarország & $\begin{array}{l}\text { 1,65 Mrd€ } \\
5300 \text { fö }\end{array}$ \\
\hline
\end{tabular}

\section{2. táblázat Az interjúk során felkeresett vállalatok adatai (saját szerkesztés)}

Az első vizsgált vállalat (V1) kiválasztására a NTP tagjainak sorából került sor. A vállalat egy régóta létező, tradicionális magyar holdig leányvállalata, amelynek feladata a vállalatcsoporton belül olyan gépek, berendezések gyártása, amelyek megfelelnek az Ipar 4.0 követelményeinek. Szenzorokkal, kamerákkal felszerelt gyártósorokat gyártanak, és jelentős hardver- és szoftverfejlesztést folytatnak. Ennek ellenére saját gyártásuk csak részben tekinthető Ipar 4.0-nak. A vállalatnál az ügyvezető igazgató válaszolt a kérdésekre, aki releváns forrásnak tekinthető a stratégiai és fejlesztési irányok témaköreiben egyaránt.

A második interjú egy amerikai nagyvállalat magyarországi fióktelepén készült. A vállalat a szerző tanszékével intenzív kapcsolatot ápol, korábban is folyt már ott Ipar 4.0-t érintő kutatás. A második vállalatot (V2) egyben az első vállalat interjúján is ajánlották. V2 magyarországi leányvállalat a nemzetközi vállalatcsoporton belül különleges pozíciót foglal el, egyike a 3 pilot-gyárnak (egy kínai és egy amerikai létesítmény mellett), amely Ipar 4.0 technológiákkal kísérletezik a csoport számára. Az interjúban megkérdezett Lean és Six-sigma vezető a gyáron belül ennek az Ipar 4.0 fejlesztő csoportnak a vezetője, és a pilot-gyár státusz kezdeményezője. E pozíciója miatt teljes rálátással rendelkezik a cégnél folyó fejlesztések irányára és a stratégiára, közvetlenül riportál nemcsak a magyar ügyvezetőnek, hanem a vállalatcsoport nemzetközi fejlesztési igazgatójának, tagja a vállalatcsoport Ipar 4.0 globális fejlesztési munkacsoportjának.

A harmadik interjút a V2 vállalat ajánlása alapján választottuk ki, és egy belga vállalatcsoport magyar leányvállalatánál zajlott (V3). A megkeresett vezető a termelöüzem vezetője, a gyárigazgató helyettese. A belga vállalatcsoporton belül e magyar létesítmény ugyancsak pilot-gyárnak számít, amely az üzemvezető és a gyárigazgató kezdeményezésére alakult ki. Ily módon teljes rálátással rendelkezik a stratégiára, a pénzügyi lehetőségekre és a fejlesztés irányaira vonatkozóan.

A negyedik vállalat (V4) nemzetközileg ismert innovativitásáról, és mivel német óriásvállalatról van szó, az Ipar 4.0 mellett is elkötelezettek. Mindenképpen cél volt a kutatás csoportvezető, habár nem vesz részt a stratégiaalkotásban és a pénzügyi tervezésben, a többi fejlesztési csoporttal szorosan együttműködik, így tisztában van a rövid és középtávú tervekkel, a fejlődés irányaival. Az interjún nemcsak az adott telephely fejlesztéseiről beszélt, hanem a vállalatcsoport más tagvállalatai által elért eredményekről, amelyhez a vállalat intranetes Ipar 4.0 oldalát és a vállalati folyóiratot is megmutatta és részletesen ismertette az interjúalany.

Összességében az interjúk révén nyert információk nem tekinthetők reprezentatívnak, de olyan vállalatok álláspontját tükrözik, akik tudatosan, napi szinten foglalkoznak az Ipar 4.0 problematikájával, tapasztalatuk és véleményük iránymutató lehet a fejlesztések elején járó, vagy az azokat fontolgató vállalkozások számára.

\section{Eredmények}

Az eredmények bemutatása során a kutatási kérdések mentén halad végig a tanulmány. Foglalkozik a vállalatok Ipar 4.0 értelmezésével, a fejlesztési folyamat lépéseivel, majd pedig a hat nehézséget jelentő faktorral. Általában elmondható, hogy az Ipar 4.0 erőteljesebben jelent meg a nemzetközi hátterü vállalatoknál, míg a magyar KKV az előbbiekhez képest szerényebb eredményeket tud felmutatni.

\section{Az Ipar 4.0 megközelítése}

A megkérdezett vállalatoknak általában megvolt a kialakult véleményük arról, mit is jelent számukra az Ipar 4.0:

„Az információ forradalma az iparban.” (V1 interjú, 2017)

„A keletkezö hatalmas mennyiségü adatot felhasználni, értelmezni, ezekből elöre jelezni, a jövőbe látni. Ez a kulcs.” (V2 interjú, 2017)

„Az Ipar 4.0 adat és viselkedés. Mindenki megkap minden számára releváns információt, hogyan és mit tud ez alapján reagálni, dönteni, ez a kulcskérdés." (V3 interjú, 2017)

„Az intelligensebbé váló ipar átfogó hálózatba kapcsolása." (V4 interjú, 2017) 
A megkérdezett vállalatok egyetértenek abban, ami a szakirodalmi áttekintésben is olvasható, hogy az Ipar 4.0 kulcsa az információ és a belőle kinyerhető adat, amelyet a hálózaton keresztül a megfelelő részlegekkel megosztva és a döntési folyamatokban felhasználva versenyelőnyre lehet szert tenni.

\section{Az Ipar 4.0 fejlesztések menete}

A megkérdezett vállalatok többféleképpen is viszonyulnak az Ipar 4.0-hoz. Van, aki a szükséges fejlesztéseket végrehajtja, nem szalad előre, nem pilot-ol, kihasználja azt, amit a technológia nyújt és könnyü (és olcsó) hozzáférni. Két olyan interjúalany is volt, ahol a vállalatcsoporton belül a magyarországi gyárak pilot-gyárak, ötletelnek, fejlesztenek, és ami beválik, implementálják a többi gyárban is. Ezek helyi, önálló kezdeményezések és a két vállalatban felkeresett dinamikus vezetőn sok múlik. A V4 vállalat már régóta ismeretes innovációs tevékenységéröl - nem csak vállalatcsoportján belül -, amely már azelőtt is a digitalizáció irányába folyt, mielőtt a német High Tech stratégia megjelent volna, és mint globális, német vállalat továbbra is missziójuknak tekintik, hogy élen járjanak (V1, V2, V3, V4 interjúk, 2017).

Az, hogy milyen fázisokon megy keresztül egy vállalat, mire ténylegesen ki tudja aknázni az Ipar 4.0 lehetőségeit, tanulságos lehet a hezitálóknak. Az első lépés mindenképpen az, hogy adatgyüjtésbe kezdenek a cégek, ahogyan arra a szakirodalom is felhívja a figyelmet. Telepítik azokat a technológiai eszközöket, esetleg szoftvereket, amelyek képesek a kívánt megfigyelésekre és az adatok gyüjtésére (V1, V2, V3, V4 interjúk, 2017). Ezt követi az adatoknak a kiválogatása és döntéstámogató információvá való átalakítása. Nagyon fontos kérdés azoknak az adatoknak az azonosítása és kiszürése, amelyek valóban hozzásegítik a vállalatot az eredményesebb müködéshez és a hatékonyabb döntéshozatalhoz: ,A sok összegyüjtött adat elsösorban a menedzsmentet támogatja. Fel lehet használni a szervezetfejlesztéshez is" (V3 interjú, 2017). Ez az egyik legkritikusabb pont az irodalom szerint is (Szalavetz, 2016; Csurgó, 2017), nagyon sok helyen hiányzik az adatelemzés és értelmezés képessége (V2, V3, V4 interjúk, 2017). A következő szint az adatokból nyert eredmények felhasználása. Ehhez szintén jól képzett munkaerő kell, akik a kinyert adatokat a szervezet megfelelő részlegei számára a kívánt struktúrában és összetettségi szinten rendelkezésre bocsátják, ahol azokat be tudják építeni a döntéseikbe, és a valós idejü adathozzáférés és -elemzés eléri célját (V2, V3 és V4 interjúk, 2017). A V4 vállalat nem csupán a vállalaton belüli nem-termelö részlegek adatellátását valósítja meg, hanem vállalatcsoport szinten is gyüjtik, elemzik és elosztják az adatokat (V4 interjú, 2017).

A megkérdezett vállalatok elindultak az Ipar 4.0 fejlödés útján és ez egy lassan bekövetkező változás, amelynek számos kihívásával szembesülnek.

\section{Az Ipar 4.0 stratégia és beruházások}

Ez az alfejezet azzal foglalkozik, mennyire jellemző, hogy a vizsgált vállalatok rendelkeznek digitális stratégiával.
V1 vállalat, annak ellenére, hogy az Ipar 4.0 technológiával felszerelt gyártósorokat gyárt, önmaga elég kezdetleges szinten jár a megvalósításban. Saját bevallása szerint is csak azokat a technológiákat veszi át, amelyekről már más vállalati példák alapján bebizonyosodott, megéri befektetni: „,Mi azokat a technológiákat használjuk, amelyek karnyújtásnyira vannak” (V1 interjú, 2017). A cég által követett digitális stratégiát leginkább digitális újoncként (Geissbauer et al., 2016) lehet jellemezni. A vállalatvezető nem kívánta megbecsülni, mennyi pénzt fog cége a következő években Ipar 4.0-hoz kapcsolódó technológiákra költeni. Véleménye egybecseng a szakirodalommal (Szalavetz, 2016; Csurgó, 2017) mert úgy látja, jó programozókra, szoftverfejlesztőkre és tervezőmérnökökre van szüksége, hogy vevői számára megfelelő termékeket legyen képes előállítani, ami ugyancsak - humán tőke beruházás.

V2 vállalat anyavállalata rendelkezik digitális stratégiával, amelynek kialakításában szerepe volt a pilot gyáraknak is. „4 éve kezdett el gondolkodni a cég. A Kutatás és Fejlesztés $(K+F)$ és az operációért felelösök összeültünk európai szinten, hogy átgondoljuk, hogyan éljünk a digitalizációval" (V2 interjú, 2017). A cég a digitális stratégiában horizontális integrátornak (Geissbauer et al., 2016) tekinthetö, aki vállalatcsoportján belül igyekszik a vertikális integrációt is megvalósítani. A vállalat nagy kiadásokkal számol minden szinten az elkövetkező években, hogy megújítsa technológiáját. Az anyavállalat jelentős keretet biztosít a pilot-jellegü fejlesztésekre, és siker esetén implementálja a megoldásokat a vállalatcsoport többi gyárában is. Azt azonban, hogy milyen megtérülésekkel lehet számolni, még nem látják tisztán.

A harmadik vállalat (V3) belga anyavállalata rendelkezik digitális stratégiával, amelyet a magyar leányvállalat is alkalmaz. A magyar telephely egyike a világon létrehozott öt fejlesztési központnak, amelyek kijelölik a fejlesztési irányokat és részt vesznek a stratégia kidolgozásában is: „Nem vevői elvárás. Jobbak akarunk lenni, mint versenytársaink. Előre menni" (V3 interjú, 2017). Digitális stratégiája horizontális integrátornak (lásd előző fejezetek és Geissbauer et al., 2016) tekinthető. Annak ellenére, hogy a magyar telephely pilot-gyár, az egyes ötletek finanszírozásáért meg kell küzdeni. Az eljárás ugyanaz, mint V2 esetén: ha sikeres a projekt, alkalmazzák az eljárást a vállalatcsoport többi gyárában is. A vállalat a következő években jelentős beruházásokkal számol, a megtérülés és a fejlesztések egymásra épülése egyaránt fontos.

V4 vállalat korábban kezdett digitális stratégiáról gondolkodni, mint ahogy az Ipar 4.0 fogalma megjelent volna. Részletes és szerteágazó digitális stratégiával rendelkezik vállalatcsoport szinten, és a stuttgarti központ a gyárak számára is meghatározza a fejlesztési irányokat: „,nagyon sokféle területen definiáltunk Ipar 4.0 projekteket termelésen belül és azon kívül egyaránt" (V4 interjú, 2017). Gyakorlatilag a gyárak szakosodnak bizonyos típusú fejlesztésekre. A felülről jövő stratégiai irányok ellenére a vállalat nagyon nyitott az alulról jövő kezdeményezésekre is. Digitális stratégiájában a vertikális integráció is megjelenik csoportszinten, és megkezdődött az üzleti modell 
újragondolása is, amely digitális bajnokká (Geissbauer et al., 2016) teszi. V4 vállalat 2016-ban csoportszinten az éves árbevétel 9,5\%-át költötte kutatásra és fejlesztésre. A beruházásoknál nagyon komolyan veszik a megtérülést, gyáron belül olyan beruházásokat támogatnak elsősorban, amelyek két éven belül megtérülnek.

A nagy, külföldi hátterü vállalatok a mintában mind rendelkeznek átfogó digitális stratégiával, lehetőségeik az anyavállalat pénzügyi lehetőségeitől is erősen függnek. A beruházásokról még anonim módon sem árultak el konkrét tervszámokat, de az látszik, hogy nagymértékü Ipar 4.0 vonatkozású beruházásokkal számolnak.

\section{Az információ kezelése és az adatbiztonság}

A fejezet bemutatja a megkérdezett vállalatok információgyűjtésre használt technológiáit és törekvéseit az információk és adatok biztonságos kezelésére.

Az adatok gyüjtésének és elemzésének kritikus voltát nemcsak a szakirodalom, hanem valamennyi interjúalany is hangsúlyozta. Ha még teljes termelési rendszereiket átfogóan nem is, de egyes gépsoraikat már felszerelték érzékelőkkel, szkennerekkel, 3D kamerával, hogy minél teljesebb képet kapjanak az ott zajló folyamatokról és begyüjthessék az adatokat. Ennek a hatalmas adatmenynyiségnek a tárolása és őrzése hatalmas feladat: ,, $A z$ adatokat hatalmas, saját szerverparkban tároljuk. Óriási beruházás" (V4, interjú, 2017). A megkérdezett vállalatok többsége egyelöre saját szervereken vagy vállalati felhőben tartja adatait, amelyhez a vállalatcsoport más tagjai férhetnek hozzá. Egy vállalat használ globális felhő szolgáltatót, de tart tőle, hogy ha ügyfeleivel ezen keresztül osztaná meg az információkat, azt nem tartanák elég biztonságosnak (V1, V2, V3, V4 interjúk, 2017).

A dolgozókról, folyamatokról, terméktervezésről, prototípusokról szóló adatok és információk védelme újfajta gondolkodást igényel a vállalatok részéről (V3 interjú, 2017). Az interjúalanyok véleménye összecseng az irodalomban olvasottakkal, hiszen ezek az adatok adott esetben a versenyelőny forrásai, és meg kell tudniuk védeni azokat az adathalászok, zsarolóvírusok, kémprogramok és egyéb kiber bünözők támadásaitól. Ezeken a területeken jelentős szabályozási változások, szigorítás várható, gondoljunk csak a 2018 májusától érvényes EU General Data Protection Regulation (GDPR) szabályozására.

Mivel nagy mennyiségü adat keletkezik a folyamatok megfigyelésével, fontos feladat azoknak a kiválogatása, amelyek tényleg hozzá fognak járulni a vállalat hatékonyabb müködéséhez. Az adatelemzés eredményeképpen elöálló információt döntéshozatalban kell felhasználni. Ez nem csak az emberi, de autonóm robotok döntéseit is támogathatja, ami egy újabb példája a mindent mindennel összekacsoló elektronikus hálózat előnyeinek. Ilyen autonóm robotot V4 vállalat már alkalmaz Magyarországon. A szóban forgó gép fémlemezt von be bevonattal. A 3D szkenner érzékeli, ha elmozdul a lemez, és félö, hogy a bevonat nem fedi teljesen a soron következő lemezt, és jelez a robotnak, amely megigazítja azt (closed loop M2M (machine2machine) - a két gép kommunikál az adatok alapján és be is avatkozik) (V4 interjú, 2017).
Geissbauer és szerzőtársai (2016) prognózisával ellentétben, az adatok vállalati partnerek közötti megosztását a megkérdezett vállalatok közül három nagyon távoli jövőnek tartja. V4 azonban akár öt éven belül megvalósíthatónak látja, hiszen vállalatcsoportja gyakorlatilag már ebben létezik. E vállalat esetében alapvető müködési modell a vevőkkel való közös terméktervezés, -fejlesztés. Beszállítói közül több a vállalatcsoport tagja, így az információk ez irányú megosztása kevésbé kockázatos (V4 interjú, 2017). Alapvetően a jelenséget távoli jövőbe helyezők azzal indokolták véleményüket, hogy ez a fajta mély, valós idejü adatmegosztás olyan mértékü bizalmat (és hálózatfejlesztési beruházást) igényelne szervezetek és emberek között, amely jelenleg még nem áll fenn - nem csak Magyarországon (V1, V2, V3, V4 interjúk, 2017). Létrejöttét akkor tudják elképzelni, ha egyértelműen, pénzértékben kifejezhető üzleti előnyhöz juttatja a céget (V3 interjú, 2017).

\section{A munkaerővel kapcsolatos problémák}

A digitális fejlődés és az emberi erőforrás viszonyának tárgyalása két ok miatt is fontos: egyrészt, sok dolgozó fél attól, hogy a digitális megoldások, robotok elveszik a munkáját. Ez lehetséges, de ekkor fel kell vázolni előtte a tanulás és a magasabb szintü munka végzésének lehetőségét, továbbá azt, hogy az új technológia megkönnyíti a munkát. Másrészt, a robotizáció és automatizáció elterjedése miatt felszabaduló munkaerő számára más lehetőséget kell találni, nem feltétlenül (csak) vállalati szinten.

A legtöbb interjúalany érzékeli a szakirodalomban is felvázolt bizalmatlanságot (Frey - Osborne, 2017; Szalavetz, 2016) munkavállalói körében az új technológiák irányában. Többségük bevonás révén igyekezett megismertetni munkavállalóival az új technológiákat, azok szükségességét. Volt, ahol ez elegendőnek bizonyult, a dolgozók elfogadták és használják az új eszközöket, az új technológiát. Volt azonban olyan válaszadó, aki a bevonás és tájékoztatás ellenére is ellenállást tapasztalt. Megrongálták a szenzorokat, interfész készülékeket, nem voltak hajlandóak követni annak utasításait. A jel közvetítésének megszünése miatt az ilyen gyorsan kiderül, de nagy költség pótolni. Ezért ebben a vállalatban autokratikus megközelítésre váltottak a bevonásról: aki nem hajlandó az új eszközökkel dolgozni, keressen új munkahelyet. Az ellenállás ellenére nem következett be tömeges elvándorlás, még annak ellenére sem, hogy ipari létesítményekkel bőven ellátott környékről van szó (V1, V2, V3, V4 interjúk, 2017).

A dolgozók felvilágosítása arról is kell, hogy szóljon, hogy munkájuk szorosabb nyomon követése révén, teljesítményük közvetlenül befolyásolja (vagy éppen fogja befolyásolni) kézhez kapott fizetésük nagyságát: „Amint elkezdünk mérni egy folyamatot, 30 százalékkal javul a teljesitmény" (V1 interjú, 2017). A jó teljesítményt tehát elismerik a mérések révén, a rosszat pedig lehet elemezni és megváltoztatni (V1, V3 interjúk, 2017).

A képzettség problémája több szinten is jelentkezhet, amint arra Frey és Osborne (2017) is rámutatnak. Az egyik legkritikusabb pont, hogy nagyon sok helyen hiányzik az 
adatelemzés és értelmezés képessége, így nagy szakemberhiány van e téren. Az elemzést ugyanis nemcsak lefuttatni kell tudni, hanem az adatbázis előzetes tisztításán át az algoritmusok ismerete, a hibák, torzító hatások felismerése, az eredmények átlátható tálalása is fontos (V2, V3, V4 interjúk, 2017).

A megkérdezett vállalatok szerint a digitális világban a különféle rendszerek használatának magabiztossága, a folyamatos tanulás és továbbképzés, az erre való belső igény nélkülözhetetlen (V1, V2, V3, V4 interjúk, 2017). A V2-nél működő rendszer szerint a dolgozó, amelyik bejelentkezik egy gépbe munkára, azonnal látja, hogy van-e jogosultsága elvégezni az adott termelési tevékenységet, megvan-e hozzá a képzettsége, vagy sem. Ha esetleg nincs, a rendszer elirányítja egy e-learning felületre, ahol gyorsan el tudja végezni a tréninget, pl. az adott gép kezelésére vonatkozóan: „Ez hozzászoktatja a munkavállalót a folyamatos tanuláshoz" (V2 interjú, 2017). A robotok miatti elbocsájtás problémája még nem merült fel: „Nagyon kevés a munkaerő. Az Ipar 4.0-ás robotok és automatizáció miatt nem elbocsájtunk, hanem így tudunk annyi embert felvenni, amennyi a termelésbe kell" (V4 interjú, 2017).

A munkaerővel kapcsolatos kérdéseket a megkérdezett vállalatok tudatosan kezelik, a korábbi ipari forradalmak géprombolásaiból tanulva próbálják megismertetni a dolgozókkal a fejlesztések munkájukra gyakorolt kedvező hatásait. Magasabb, elemzői programozói szinten a szakemberekhez hozzájutás nagyon nehéz.

\section{Szabványosítási problémák}

A szabványosítási problémák több szinten is megjelennek. Nemcsak a vállalaton belüli eszközök, rendszerek között, hanem a vállalatok közötti kapcsolatokban is, amely a digitális ökoszisztéma kialakulásának technológiai akadálya.

A megkérdezett vállalatok elsősorban házon belül szembesülnek a szabványosítási problémával. A fejlesztések elsődlegesen az adatok szüréséhez, elemzéshez használt szoftverekre irányulnak: „Az analitikus eszközöket szoftverfejlesztöink a felhasználóval együtt fejlesztik” (V4 interjú, 2017), ami egybecseng a SZTAKI megállapításaival (Nick, 2017). Az így kapott információkat pl. a vállalati ERP-rendszerekbe közvetítő interfészeknek kulcsszerepük van, a legtöbb vállalat ezeket is maga fejleszti. V3 és V4 jelentős összegeket költ erre (V3, V4 interjúk, 2017). Azok az applikációk is nagyon elterjedtek, amelyek a keletkezett és feldolgozott információkat a felhasználó számára könnyen kezelhető platformokon (mobiltelefon, tablet) jelenítik meg: ,, Mi egy magyar start-up-pal dolgozunk együtt. Elemzö szoftvereket és telefonos applikációt fejlesztünk, amiket kompatibilissé kell tenni többi rendszerünkkel" (V3 interjú, 2017).

Egy vállalaton belül is nehéz biztosítani az összeköttetést a különböző szintü és bonyolultságú rendszerek, az adattárházak és elemző szoftverek között: ,,Rengetegféle rendszert használunk IT-ban" (V3 interjú, 2017), még nehezebb azonban, ha az adatmegosztás partnerek közt történik. „Beszállítóinkkal folytattunk pilot projekteket” (V2 interjú, 2017), és azok a rendszerek összekapcsolásának nehézségei, valamint az eltérő fejlettség miatt meghiúsultak. V4 vállalat vevőivel, az autógyárakkal végez közös fejlesztéseket: ,,nagyon sokféle területen definiáltunk Ipar 4.0 projekteket termelésen belül és azon kívül egyaránt. Vevőinkkel is vannak közös projektjeink" (V4 interjú, 2017).

A megkérdezett vállalatok mindannyian kritikusnak nevezték a szoftverfejlesztői tudást a szervezetben, és aggodalmukat fejezték ki a szabványok hiánya és a szakember-utánpótlás biztosítása miatt.

\section{Az intellektuális vagyon}

A korábbi fejezetekben bemutattuk, hogy mennyire szerteágazó területeken zajlanak fejlesztések a vállalatban. A gépek, berendezések fejlesztése, új technikai találmányok (pl. robotok, kiterjesztett valóságra épülő eszközök), szabadalmak, a rengeteg egyedileg fejlesztett szoftver mind a vállalat intellektuális vagyonát növeli. Az Ipar 4.0 jelenlegi, felfutási szakaszában jellemző ezeknek a saját fejlesztése, később, a szabványok megjelenésével, standard programcsomagok elérhetővé válásával, a technológiai berendezések árának további csökkenésével terjedésük széles körüvé válik: „Csoportszinten, 2016 folyamán világszerte több mint 1200 szabadalmat jegyeztettünk be” (V4 interjú, 2017).

V4 vállalatcsoport madridi egységében dolgozik egy adatbányász részleg, amely ultrahang-érzékelők gyártásának adatait rendszerezi. A gyártásban három helyen is keletkezik adat, a MES-ben (Manufacturing Execution System), a tesztelés során és a gyártásban részt vevő gépek beállításaiból. Ez napi 170 GB mennyiségü adat, csak ezen a részlegen. A feldolgozáshoz speciális számítógépfürtbe töltik fel az adatokat, és internetes böngészőkben használatos keresőmotorok segítségével gyorsítják fel a szürést, elemzést. A rendszer gyakorlatilag minden információt képes mindennel összekapcsolni, így rendkívül összetett ok-okozati kapcsolatokra is fény derülhet (V4 interjú, 2017). Az ilyen technológiák kifejlesztése rengeteg anyagi és emberi erőforrást igényel, amint arra Heynitz és szerzőtársai (2016) is rámutatnak.

A vállalati tudásbázis fejlesztése a szakirodalomnak megfelelően a vizsgált vállalatoknál is fontos feladat, amelynek érdekében a vállalatok különféle programokat indítottak. V1 vállalat belső képzést dolgozott ki alkalmazottai számára, amely során adatfeldolgozásra, szürésre, valamint elemzésre oktatják a dolgozókat. Ez nemcsak tananyagfejlesztést jelent, de annak folyamatos frissen tartása, újabb képzések kialakítása is nagy feladat (V1 interjú, 2017). V2 már sok éve dolgoz ki e-learning tananyagokat a dolgozók tréningezésére, amely nemcsak egy új gép használatára való kiképzést foglalhat magába, de munkavédelmi, tűzvédelmi oktatást és karbantartás szimulációt is (V2 interjú, 2017). V3-nál is működik az előbbiekben említett, gépkezelési e-learning felület, igaz nem régóta. A vállalat az interjúban inkább szellemi dolgozóik továbbképzéséről beszélt, akiket csapatban dolgozás, rosszul strukturált problémák elemzése, adatbányászat és -elemzés témákban tréningeznek rendszeresen, egyes 
témákat szimulációs játékok révén, és úgy gondolják ezeknek a készségeknek a fejlesztése elengedhetetlen az Ipar 4.0 környezetben (V3 interjú, 2017).

A megkérdezett vállalatok mind jelentős összegeket fordítanak technológiájuk fejlesztésére, egyes esetekben szabadalmakra, valamint kollégáik képzésére. Az intellektuális vagyon fejlesztése tehát központi kérdés, elengedhetetlen az Ipar 4.0 környezetben. Azon félelmének egyik vállalat sem adott hangot, hogy ne éreznék biztonságban e vagyonukat.

\section{Az eredmények értékelése}

Az eredmények értékelése során a tanulmány azt tekinti át, hogy az interjúk és a szakirodalom révén milyen következtetések vonhatók le a kutatási kérdésből.

Az első kutatási kérdés a megkérdezett vállalatok Ipar 4.0 értelmezését vizsgálta. Mindannyian elindultak már az Ipar 4.0-ához kapcsolható fejlesztések útján. Az interjúkból is kitünik, hogy amint azt Heynitz és szerzőtársai (2016), valamint Geissbauer és szerzőtársai (2016) is megállapították az Ipar 4.0 föként a termeléshez, adatokhoz, technológiához kapcsolódik és részben folyamatalapú. Hermann és szerzőtársai (2016) és Horváth és Szabó (2017) állításai is igazolást nyernek, mert a megkérdezett vállalatok jelentős szervezeti, szervezési vonatkozásokat is érzékelnek.

A második kutatási kérdés azt a fejlődési útvonalat vizsgálta, amelyen keresztül az Ipar 4.0 megoldások megjelennek és kiteljesednek a vállalatban. Az elméleti részben bemutatott négyszakaszos fejlődésnek a vizsgált vállalatok esetében föként kezdeti stádiumai figyelhetők meg. Zhou és szerzőtársai (2015) megfigyelésével egybevág, hogy a kezdeti lépés a termelés digitalizálása, az adatgyüjtés, valamint azoknak az információknak a kiszürése, amelyek szükségesek lesznek a fejlesztésekhez, döntéshozatalhoz, és ezeknek a szervezeten belüli elosztása. A horizontális integráció a külföldi tulajdonú vállalatok esetében részben (V2, V3), vagy egészben (V4) megvalósul, vertikális integrációról csak V4 vállalat esetében beszélhetünk, de V2 és V3 is elindult ebbe az irányba, elsősorban vállalatcsoport szinten. Az üzleti modell újragondolása a Porter és Heppelmann (2014) által felvázolt kiterjedésben V4 vállalatnál kezdődött meg globális szinten. Meg kell azonban jegyezni, hogy a vállalatnál tapasztalt fejlődési útvonal, az Ipar 4.0 kiteljesedésének folyamata nem esik egybe az elméletben felvázoltakkal. A cégek az adatgyüjtési és -elemzési szakaszok kialakítását jobban tagolják, maximum a horizontális integrációig látnak el (kivéve V4, abban az esetben, ha a vállalatcsoporttal való integrációt nem tekintjük igazi vertikális integrációnak) (3. táblázat).
A harmadik kutatási kérdés az irodalomban azonosított kritikus problémakörök megjelenését vizsgálta. Az Ipar 4.0 megvalósítását megnehezítő faktorok közül a digitális stratégia hiánya, amit Geissbauer és szerzőtársai (2016) is kiemelnek, leginkább a magyar KKV-t érinti, amelynek nincs formalizált startégiája e téren, míg a nemzetközi hátterü cégek mindannyian rendelkeznek vele - anyavállalatuk jóvoltából. V2 és V3 esetében a magyar leányvállalat szerepet is vállalt a stratégia kialakításában. A beruházások színvonala nem volt megítélhető az interjúk alapján, mivel konkrét összegek nem hangzottak el. A beruházások jelentőségét minden interjú megerősítette, mindegyik vállalat fejlődést tervez e téren, nemcsak technológiában, hanem jelentős mértékben az intellektuális vagyonban is. Az e-beszamolo.im.gov.hu adatai szerint V1 vállalat csaknem teljes 2015-ös nettó árbevételét, 104 millió forintot költött 2016 során kutatás-fejlesztésre. V2 vállalat beruházásai 2016 során csaknem 21 százalékkal nőttek, V3 ugyanebben az évben 10 százalékkal növelte müszaki gép, berendezés, további 8 százalékkal egyéb gép, berendezés állományát. V4 beruházásai 2016-ban megduplázódtak 2015-höz képest (e-beszamolo.im.gov.hu, 2018).

Az információ és adatbiztonság kérdésében Mansfield-Devine (2016) szerint a cégek nincsenek felkészülve, hogy kezeljék az IoT által létrejött adatmennyiséget és azt, hogy az eszközök mind kapcsolódnak a hálózathoz és ezáltal hozzáférhetőek. A megkérdezett vállalatok mind megkezdték már berendezéseik adatgyüjtő egységekkel, hálózathoz csatlakozást lehetővé tevő eszközökkel való felszerelését. Amint azt Masfield-Devine is megfogalmazza, a biztonság megteremtésének legegyszerübb módja a hálózat korlátozása (pl. egyszerü helyi hálózat), amelyet a megkérdezett vállalatok többsége alkalmaz is, továbbá a saját szerverpark üzemeltetése. A válaszadó vállalatok szerint azonban az adatmennyiség növekedésével nem lesznek fenntarthatók a házon belüli adattárházak, és ez komoly kihívást jelent.

A legtöbb válaszadó a fejlesztésekbe bevonja azokat a kollégákat, akik majd az új eszközt, szoftvert használni fogják, hiszen így biztosítható a motiváció és az elkötelezettség, valamint az innovációs hajlandóság is nő, amely igazolja Bácsi (2017) megállapításait. A munkaerővel kapcsolatos legfontosabb észrevétel az interjúalanyok részéről a nagyfokú hiány, ami a magasan képzett, adattudományban, szoftver-, hardverfejlesztésben jártas dolgozók esetén jelentkezik. Frey és Osborne (2017) jóslata részben tehát már igaz: a magasan képzett, IoT és okoseszközök kezelésére, tervezésére képes szakemberekből hiány van, ugyanakkor a fizikai dolgozók tömeges kiváltására a közeljövőben nem kerül még sor.

\begin{tabular}{|c|c|c|c|c|c|c|}
\hline $\begin{array}{l}\text { Technológia, eszköz } \\
\text { vállalat }\end{array}$ & $\begin{array}{l}\text { Adatgyüjtő eszköz (RFID, } \\
\text { szenzor, 3D szkenner) }\end{array}$ & $\begin{array}{l}\text { Big data } \\
\text { elemzés }\end{array}$ & $\begin{array}{l}\text { Vállalati szerverek } \\
\text { vagy felhö }\end{array}$ & $\begin{array}{l}\text { Felhö- } \\
\text { szolgáltató }\end{array}$ & $\begin{array}{l}\text { Autonóm } \\
\text { robot }\end{array}$ & $\begin{array}{l}\text { M2M } \\
\text { kommunikáció }\end{array}$ \\
\hline V1 & $\mathrm{X}$ & & $\mathrm{X}$ & & & \\
\hline $\mathrm{V} 2$ & $\mathrm{X}$ & $\mathrm{X}$ & $\mathrm{X}$ & & $\mathrm{X}$ \\
\hline $\mathrm{V} 3$ & $\mathrm{X}$ & $\mathrm{X}$ & $\mathrm{X}$ & $\mathrm{X}$ & & \\
\hline $\mathrm{V} 4$ & $\mathrm{X}$ & $\mathrm{X}$ & $\mathrm{X}$ & $\mathrm{X}$ & $\mathrm{X}$ & $\mathrm{X}$ \\
\hline
\end{tabular}


A megkérdezett vállalatok többsége a horizontális integráció fázisában van (Geissbauer et al., 2016), és onnan készül továbblépni. Saját fejlesztésű programjaik, interfészeik létrehozására rengeteg pénzt költenek és beszállítóikkal, vevőikkel való pilotok igazolják, hogy a szabványok hiánya a projekt gátja és többletköltséget okoz.

Az intellektuális vagyon felhalmozása megkezdődött szabadalmak, szoftver és hardverfejlesztések, a dolgozók tudásába való invesztíció formájában, mert oktatási programot, továbbképzést a hiányszakmákban kialakítottak a válaszadó vállalatoknál. Felismerték, amit Clarke és szerzőtársai (2011) is megfogalmaznak, hogy az Ipar 4.0 megvalósítása és a fejlődéssel a lépés tartása során nekik maguknak kell jelentős összegeket fordítaniuk mind a technológiára, mind dolgozóik fejlesztésére, szinten tartására, hiszen enélkül nem lesznek versenyképesek.

\section{Konklúzió}

A tanulmány célja az volt, hogy tisztázza az Ipar 4.0 fogalmát, megismertesse az olvasókat a fóbb technológiákkal és azokkal a szintekkel, ahogyan egy vállalatban, majd vállalatok és szervezetek kapcsolatában kiteljesedik a digitalizáció hatása.

A tanulmány hozzájárulása az elméleti szakirodalomhoz a digitalizáció technológiai hátterének, eszközeinek, szervezési megoldásainak és mindezek összefüggéseinek áttekinthető bemutatásában és ábrázolásában (1. ábra) mutatkozik meg. Ugyancsak fontos a digitalizációt övező általános lelkesedés mellett a bevezetés problémáinak, gátjainak áttekintése, az erre vonatkozó szakirodalom öszszefoglalása.

A gyakorló vállalati szakemberek számára a fejlődés menete és a problémakörök gyakorlati megjelenését bemutató, négy vállalatnál készült interjúk szolgálhatnak gondolatébresztőként, benchmarkként, amelyek felhívják a figyelmet a kritikus kérdésekre.

A kutatás eredményei a módszertanból fakadóan limitáltak. A négy vállalat kiválasztása nem reprezentatív módon történt, nem is tekinthetők a magyar ipar átlagos vállalatainak. Szerepük az, hogy jó példákat felmutatva benchmarkként szolgáljanak más vállalatok fejlődése számára.

Az Ipar 4.0-t tanulmányozó kutatások nagy számban és számos irányban folynak. Jelen kutatás is folytatódhat az akadályozó tényezők körének mind átfogóbb feltárásával. Az eredmények tovább árnyalhatók, ha az interjúk köre bővül, esetleg más iparágból és a KKV-k köréből is több vállalati szakember mondja el véleményét a fenti kérdésekben.

\section{Felhasznált irodalom}

Atzori, L. - Iera, A. - Morabito, G. (2010): The internet of things: A survey. Computer Networks, 54(15), p. 2787-2805. DOI: https://doi.org/10.1016/j.comnet.2010.05.010

Bácsi, K. (2017): Miért és mikor jó a bevonás? - érvek munkáltatói és munkavállalói oldalon. Vezetéstudomány/Budapest Management Review, 48(8-9), p. 1321.
Brettel, M. - Friederichsen, N. - Keller, M. - Rosenberg, M. (2014): How virtualization, decentralization and network building change the manufacturing landscape: An Industry 4.0 Perspective. International Journal of Mechanical, Industrial Science and Engineering, 8(1), p. 37-44. DAI: http://waset.org/Publication/9997144

Clarke, M. - Seng, D. - Whiting, R. H. (2011): Intellectual capital and firm performance in Australia. Journal of Intellectual Capital, 12(4), p. 505-530. DOI: https://doi. org/10.1108/14691931111181706

Csurgó, D. (2017): Az asztalosnak is értenie kell a robotokhoz. Interjú Rainer Strack-kal, a BCG senior partnerével. Index, 2017. október 20. http://index.hu/gazdasag/2017/10/20/rainer_strack_bcg_interju/ Letöltés dátuma: 2017.10.20

Deloitte (2015): Industry 4.0 - An introduction. Deloitte, Hollandia https:/www2.deloitte.com/content/ dam/Deloitte/be/Documents/Operations/2015_Industry\%204\%200\%20Report\%20vFinal.pdf Letöltés dátuma: 2017.07.20.

E-beszamolo.im.gov.hu: V1, V2, V3, V4 vállalatok Kiegészítő mellékleteinek letöltése. Letöltés ideje: 2018.07.31. www.e-beszamolo.im.gov.hu

Frey, C. B. - Osborne, M. A. (2017): The future of employment: how susceptible are jobs to computerisation? Technological Forecasting and Social Change, 114, p. 254-280. DOI: https://doi.org/10.1016/j.techfore.2016.08.019

Geissbauer, R. - Vedso, J. - Schrauf, S. (2016): Industry 4.0: Building the digital enterprise. PricewaterhouseCoopers LLP, Németország

Greenwood, J. - Jovanovic, B. (1999): The informationtechnology revolution and the stock market. American Economic Review, 89(2), p. 116-122.

Hazen, B. T. - Boone, C. A. - Ezell, J. D. - Jones-Farmer, L. A. (2014): Data quality for data science, predictive analytics, and big data in supply chain management: An introduction to the problem and suggestions for research and applications. International Journal of Production Economics, 154, p. 72-80. DOI: https://doi. org/10.1016/j.ijpe.2014.04.018

Hermann, M. - Pentek, T. - Otto, B. (2016, January): Design principles for industrie 4.0 scenarios. In: System Sciences (HICSS), 2016 49th Hawaii International Conference on. IEEE, p. 3928-3937. DOI: https://doi. org/10.1109/HICSS.2016.488

Heynitz, H.v. - Bremicker, M. - Amadori, D. M. - Reschke, K. (2016): The factory of the future. KPMG AG, Németország https:/assets.kpmg.com/content/dam/ kpmg/es/pdf/2017/06/the-factory-of-the-future.pdf Letöltés dátuma: 2017.07.20.

Hofmann, E. - Rüsch, M. (2017): Industry 4.0 and the current status as well as future prospects on logistics. Computers in Industry, 89, p. 23-34. DOI: http://dx.doi. org/10.1016/j.compind.2017.04.002

Holodny, E. (2017): A key player in China and the EU's ,third industrial revolution" decribes the economy of tomorrow. Business Insider, 2017.07.16. http:/www. 
businessinsider.com/jeremy-rifkin-interview-2017-6 Letöltés dátuma: 2017. 10. 20.

Horváth, D. - Mitev, A. (2015): Alternatív kvalitatív kutatási kézikönyv. Budapest: Alinea Kiadó

Horváth, D. - Szabó, Zs. R. (2017): A negyedik ipari forradalom vezetési aspektusai. Budapest: Budapesti Corvinus Egyetem, Corvinus Kutatások. http://unipub. lib.uni-corvinus.hu/3305/1/Javitott_konf_kiadvany_u. pdf Letöltés dátuma: 2018.07.23.

Jensen, M. C. (1993): The modern industrial revolution, exit, and the failure of internal control systems. The Journal of Finance, 48(3), p. 831-880. DOI: https://doi. org/10.1111/j.1540-6261.1993.tb04022.x

Kovács, O. (2017): Az ipar 4.0 komplexitása-I. Közgazdasági Szemle, 64(7/8), p. 823. DOI: http://dx.doi. org/10.18414/Ksz.2017.7-8.823

Laney, D. (2001): 3D Data Management: Controlling Data Volume, Velocity and Variety. META Group Research Note, 6, p.1-3.

Lee, J. - Kao, H. A. - Yang, S. (2014): Service innovation and smart analytics for industry 4.0 and big data environment. Procedia Cirp, 16, p. 3-8. DOI: https:// doi.org/10.1016/j.procir.2014.02.001

Mansfield-Devine, S. (2016): Securing the Internet of Things. Computer Fraud \& Security, 2016(4), p. 1520.

Mokyr, J. (1998): The second industrial revolution, 18701914. Storia dell'economia Mondiale, p. 219-245.

Mokyr, J. (ed.). (1985): The economics of the industrial revolution. New Jersey: Rowman and Allanheld Publishers

Monostori, L. (2014): Cyber-physical production systems: roots, expectations and R\&D challenges. Procedia Cirp, 17, p. 9-13. DOI: https://doi.org/10.1016/j.procir.2014.03.115

Müller, J. - Dotzauer, V. - Voigt, K. I. (2017): Industry 4.0 and its impact on reshoring decisions of German manufacturing enterprises. In: Supply Management Research. Wiesbaden: Springer, Gabler, p. 165-179. DOI 10.1007/978-3-658-18632-6_8

Nick, G. A. (2017): Az Ipar 4.0 Nemzeti Technológiai Platform támogató szerepe. XXIV. NMK Plenáris ülés, Balatonalmádi, 2017. szeptember 14. https://www.isoforum.hu/media/programnaptar/ files/NickGabor-eloadas.pdf Letöltés dátuma: 2017.10.20.
Porter, M. E. - Heppelmann, J. E. (2014): How smart, connected products are transforming competition. Harvard Business Review, 92(11), p. 64-88.

Prause, G. (2015): Sustainable business models and structures for Industry 4.0. Journal of Security and Sustainability Issues 5(2), p. 159-169. DOI: http://dx.doi. org/10.9770/jssi.2015.5.2(3)

Rüssmann, M. - Lorenz, M. - Gerbert, P. - Waldner, M. Justus, J. - Engel, P. - Harnisch, M. (2015): Industry 4.0: The future of productivity and growth in manufacturing industries. Boston Consulting Group, 9. https:// www.zvw.de/media.media.72e472fb-1698-4a15-8858344351c8902f.original.pdf Letöltés ideje: 2017.07.19.

Schwab, K. (2016): Fourth industrial revolution: what it means, how to respond. World Economic Forum, p. 1-8.

Szalavetz, A. (2016): Az ipar 4.0 technológiák gazdasági hatásai - Egy induló kutatás kérdései. Külgazdaság, 60(7-8), p. 27-50.

V1 - Vállalati interjú, 2017.07.05., Székesfehérvár

V2 - Vállalati interjú, 2017.07.06., Esztergom

V3 - Vállalati interjú, 2017.07.26., Kecskemét

V4 - Vállalati interjú, 2017.08.08., Hatvan

Van Krevelen, D. W. F. - Poelman, R. (2010): A survey of augmented reality technologies, applications and limitations. International Journal of Virtual Reality, 9(2), p.1.

Wang, S. - Wan, J. - Li, D. - Zhang, C. (2016a): Implementing smart factory of industrie 4.0: An outlook. International Journal of Distributed Sensor Networks, 12(1), 3159805. DOI: https://doi.org/10.1155/2016/3159805

Wang, G. - Gunasekaran, A. - Ngai, E. W. - Papadopoulos, T. (2016b): Big data analytics in logistics and supply chain management: Certain investigations for research and applications. International Journal of Production Economics, 176, p. 98-110. DOI: https://doi. org/10.1016/j.ijpe.2016.03.014

Weyer, S. - Schmitt, M. - Ohmer, M. - Gorecky, D. (2015): Towards Industry 4.0-Standardization as the crucial challenge for highly modular, multi-vendor production systems, Ifac - Papers online, 48, p. 579-584. DOI: https://doi.org/10.1016/j.ifacol.2015.06.143

Zhou, K. - Liu, T. - Zhou, L. (2015):: Industry 4.0: Towards future industrial opportunities and challenges. In: Fuzzy Systems and Knowledge Discovery (FSKD), 2015 12th International Conference on. IEEE, p. 2147-2152. 